\title{
Diesel Exhaust Particles Enhance MUC4 Expression in NCl-H292 Cells and Nasal Epithelial Cells via the p38/CREB Pathway
}

\author{
Il-Ho Park ${ }^{a}$ Ju-Hyung Kang ${ }^{b}$ Jin Ah Kim ${ }^{b}$ Jae-Min Shin ${ }^{a}$ Heung-Man Lee ${ }^{a-c}$ \\ ${ }^{a}$ Department of Otorhinolaryngology, Head and Neck Surgery, Guro Hospital, Korea University College of \\ Medicine, ${ }^{\mathrm{b}}$ Department of Biomedical Sciences, Korea University Graduate School, and ${ }^{\mathrm{C}}$ Medical Devices Support \\ Center, Guro Hospital, Korea University, Seoul, South Korea
}

\section{Key Words}

Vehicle emissions - Epithelium - Diesel exhaust particles . MUC4 - p38 mitogen-activated protein kinases $\cdot$ Nose

\begin{abstract}
Background: Diesel exhaust particles (DEPs), the major contributors to air pollution, induce inflammatory responses in the nasal epithelium. Overproduction of airway mucins is an important pathogenic finding in inflammatory airway diseases. Objective: The aims of the present study were to determine the effect of DEPs on the expression of the mucin gene MUC4 and to investigate the underlying mechanism of DEP-induced MUC4 expression in NCl-H292 cells and primary nasal epithelial cells (PNECs). Methods: $\mathrm{NCl}-\mathrm{H} 292$ cells were stimulated for $24 \mathrm{~h}$ with DEPs. Messenger RNA (mRNA) and protein expression of MUC4 was determined by realtime reverse transcription (RT) polymerase chain reaction (PCR) and Western blotting. $\mathrm{NCl}-\mathrm{H} 292$ cells were exposed to 3 mitogen-activated protein kinase inhibitors (U0126, SB203580, and SP600125) and a CREB (CAMP response element-binding protein) inhibitor prior to stimulation with DEPs, and MUC4 expression was examined by RT-PCR and Western blotting. PNECs were pretreated with a p38 inhibitor and CREB inhibitor prior to stimulation with DEPs, and
\end{abstract}

MUC4 expression was then determined by RT-PCR and/or Western blotting. Results: DEPs significantly increased the expression of MUC4 mRNA and protein. MUC4 mRNA and protein expression was inhibited by pretreatment with $\mathrm{p} 38$ and CREB inhibitors in $\mathrm{NCl}-\mathrm{H} 292$ stimulated with DEPs. p38 and CREB inhibitors also blocked the expression of MUC4 mRNA and protein in DEP-stimulated PNECs. Conclusions: We demonstrated that DEPs stimulated the expression of MUC4 via the p38/CREB pathway in NCl-H292 cells and PNECs. The results of the present study pave the way for further studies on the role of MUC4 in DEP-induced hypersecretion in airway epithelium.

(c) 2017 S. Karger AG, Basel

\section{Introduction}

Airway-lining fluid or mucus secretion serves as the first line of defense against inhaled irritants that can enter the lungs. The inhaled dust, microbes, and gases can damage the airway epithelium [1]. Airway mucus traps the inhaled toxins and transports them out of the airways

I.-H.P. and J.-H.K. contributed equally to this work.

\section{KARGER}

(c) 2017 S. Karger AG, Basel

E-Mail karger@karger.com

www.karger.com/iaa
Correspondence to: Dr. Heung-Man Lee

Department of Otorhinolaryngology, Head and Neck Surgery

Guro Hospital, Korea University College of Medicine

148 Gurodong-ro, Guro-gu, Seoul 08308 (South Korea)

E-Maillhman@ korea.ac.kr 
with the help of ciliary movements [2]. The most important components of the airway mucus are water and mucins. Mucins are heavily glycosylated glycoproteins with variable numbers of tandem repeats of certain amino-acid sequences that are rich in serine, threonine, and proline. At least 22 mucin genes have been cloned from humans. There are two kinds of mucin gene products. One is characterized as secreted and the others are membrane tethered. Transmembrane mucins are mostly expressed on the apical side of mucosal epithelium and are supposed to have a defensive role for the host [3]. MUC4 is a member of the transmembrane mucin family, and it is expressed in airway epithelial cells. Abnormal expression of MUC4 has been reported in various inflammatory diseases and cancers [4].

Exhaust fumes from diesel engines are the dominant source of atmospheric contamination [5]. Incomplete combustion of diesel fuels produces a complex mixture of gaseous and diesel exhaust particles (DEPs), which affect urban air quality and human respiratory health [6]. In epidemiological studies, it has been reported that the rates of respiratory disease morbidity are high in populations exposed to DEPs $[7,8]$. Many researchers have explored the mechanisms by which DEPs induce respiratory disease. The most well-known findings have revealed the proinflammatory effects of DEPs on the airways [9]. The relationship between DEPs and mucus secretion is another focus. In a study on human middle ear epithelial cells, exposure to DEPs increased the expression of MUC5AC, a secreted form of mucin [10]. Goblet cell hyperplasia of the nasal mucosa was also observed in a group of officers occupied with clearing diesel vehicles over 5 years [11].

Based on the above findings, we hypothesized that DEPs can also affect the expression of transmembrane mucins such as MUC4 in the respiratory epithelium. In the present study, we investigated whether DEPs could stimulate MUC4 mucin production in primary nasal epithelial cells (PNECs) and identified the downstream pathways such as the mitogen-activated protein kinase (MAPK) pathway, which is known to be triggered following exposure of human respiratory epithelial cell lines to DEPs.

\section{Materials and Methods}

\section{Reagents}

DEPs (SRM 2975; National Institute of Standards and Technology, Gaithersburg, MD, USA) used in this study were suspended in sterile saline $(\mathrm{NaCl} 0.9 \%)$ containing Tween 80 (0.01\%). To minimize aggregation, particle suspensions were sonicated for $15 \mathrm{~min}$

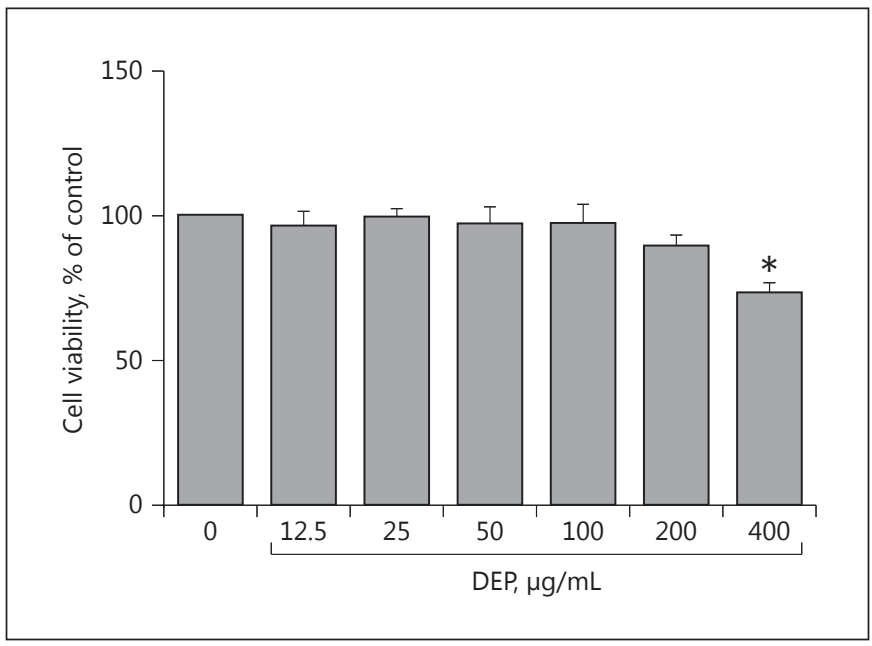

Fig. 1. Cytotoxicity test using the MTT assay at various concentrations of DEPs in NCI-H292 cells. Means \pm SEM of 3 independent experiments. ${ }^{*} p<0.05$ vs. control. DEPs, diesel exhaust particles.

and vortexed prior to use. Inhibitors of extracellular signal-regulated kinase (ERK) (U0126), p38 (SB203580), c-Jun N-terminal kinase (JNK) (SP600125), and CREB (cAMP response element-binding protein) (CAS 92-78-4) were purchased from Calbiochem (Billerica, MA, USA). MTT, 3-(4,5-dimethylthiazol-2-yl)-2,5-diphenyl tetrazolium bromide, was obtained from Sigma (St. Louis, MO, USA). Antibodies against MUC4, phosphorylated (p)-p38, totalp38, and $\beta$-actin were obtained from Santa Cruz Biotechnology (Santa Cruz, CA, USA). p-CREB and total-CREB antibodies were obtained from Cell Signaling Technology (Danvers, MA, USA).

\section{Cell Culture}

NCI-H292 (human lung mucoepidermoid carcinoma cell line) cells were obtained from the American Type Culture Collection (Manassas, VA, USA). NCI-H292 cells were cultured in RPMI 1640 medium containing $10 \%(\mathrm{v} / \mathrm{v})$ heat-inactivated fetal bovine serum (Invitrogen, Carlsbad, CA, USA), 1,000 unit/mL penicillin, and $1,000 \mu \mathrm{g} / \mathrm{mL}$ streptomycin (Invitrogen).

Inferior turbinate mucosal specimens were obtained from 5 patients during endoscopic sinus surgery for benign tumors at the Department of Otorhinolaryngology at the Korea University Guro Hospital. None of the patients had a history of allergies, asthma, or aspirin sensitivity, and neither of them received steroids, nonsteroidal anti-inflammatory drugs, antihistamines, or antibiotics during the 4 weeks prior to the biopsy. Epithelial cells were detached from the human nasal tissue by dispase II ( $1 \mathrm{U} / \mathrm{mL}$ ) (StemCell Technologies, Vancouver, BC, Canada), followed by filtration and centrifugation. The cells were suspended in BEBM (bronchial epithelial cell basal medium) supplemented with $2 \mathrm{~mL}$ bovine pituitary extract, $0.5 \mathrm{~mL}$ insulin, 1,027 $\mathrm{M}$ hydrocortisone, $0.5 \mathrm{~mL}$ retinoic acid, $0.5 \mathrm{~mL}$ transferrin, $0.5 \mathrm{~mL}$ epinephrine, $0.5 \mathrm{~mL}$ human epidermal growth factor (Lonza, Basel, Switzerland), and retinoic acid $(1 \mu \mathrm{g} / \mathrm{mL})$. The cells were maintained at $37^{\circ} \mathrm{C}$ in $5 \% \mathrm{CO}_{2}$ and $95 \%$ air, and were allowed to adhere to the culture plate for 3 days. The study was approved by the Institutional Review Board of the Korea University Guro Hospital (KUGH12041-001). 


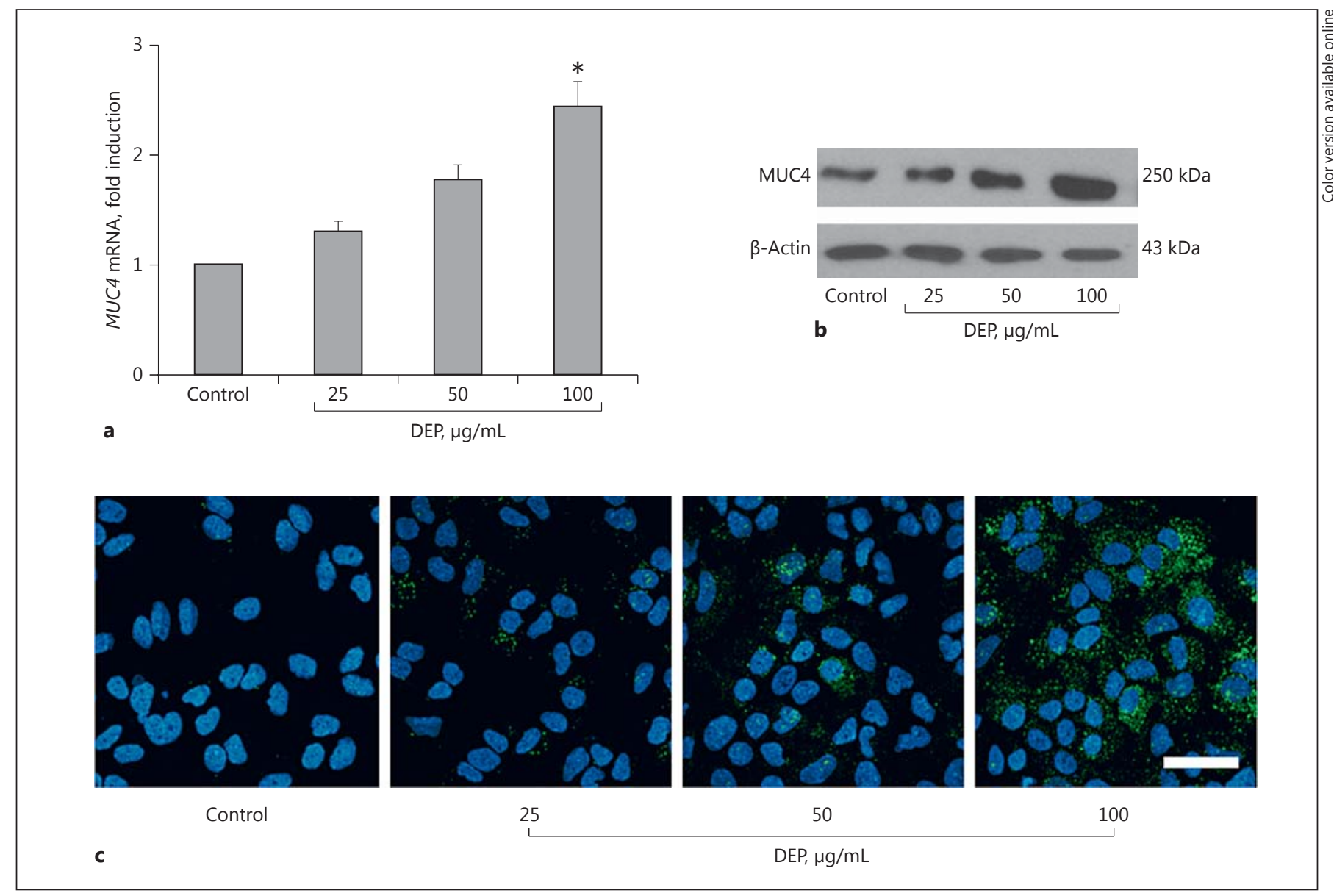

Fig. 2. Expression of MUC4 mRNA and protein in NCI-H292 cells stimulated with DEPs. NCI-H292 cells were treated with DEPs, and expression of MUC4 mRNA and protein was determined by RT-PCR (a), ELISA (b), and immunofluorescence staining (c). Means \pm SEM of 3 independent experiments. ${ }^{*} p<0.05$ vs. control. Scale bar, $20 \mu \mathrm{m}$.

\section{MTT Assay}

To determine the cytotoxic effects of DEP in NCI-H292 cells, the MTT assay was used. Cells $\left(1 \times 10^{4}\right.$ cells/well in 96-well plates $)$ were incubated with MTT for $4 \mathrm{~h}$, and the reaction was terminated by the addition of dimethyl sulfoxide. A fluorescence microplate reader (F2000; Hitachi, Ltd., Tokyo, Japan) was used to determine the results $(570 \mathrm{~nm})$.

\section{Immunofluorescent Staining of MUC4}

NCI-H292 cells $\left(5 \times 10^{4}\right.$ cells/well in 24 -well plates $)$ were fixed with $4 \%$ paraformaldehyde. Cells were then permeabilized with $0.2 \%$ Triton $\mathrm{X}-100$ in $1 \%$ bovine serum albumin for $10 \mathrm{~min}$, blocked with $5 \%$ bovine serum albumin for $1 \mathrm{~h}$ at room temperature, and incubated overnight at $4{ }^{\circ} \mathrm{C}$ with rabbit anti-human MUC4 antibody. The cells were then incubated with DyLight 488 horse anti-rabbit IgG antibody (Vector Laboratories, Burlingame, CA, USA). Finally, the cells were counterstained with $4^{\prime}, 6$-diamidino-2-phenylindole (Invitrogen). The immunostained cells were captured and visualized using a confocal microscope (LSM700; Zeiss, Oberkochen, Germany).

Diesel Exhaust Particles in the Airways
Reverse Transcription Polymerase Chain Reaction

Total RNA ( $3 \times 10^{5}$ cells/well in 6 -well plates $)$ was isolated according to the manufacturer's recommendations using TRIzol reagent (Invitrogen). Reverse transcription (RT) was performed with $2 \mu \mathrm{g}$ of RNA per sample. Total RNA was denatured at $65^{\circ} \mathrm{C}$ for $5 \mathrm{~min}$ and cooled on ice. Denatured total RNA was added to 10 $\mu \mathrm{L}$ of $5 \times$ reverse transcriptase buffer, $5 \mu \mathrm{L}$ of $2.5-\mathrm{mM}$ dNTP mix, $1 \mu \mathrm{L}$ of RNase inhibitor, and $1 \mu \mathrm{L}$ of Moloney murine leukemia virus reverse transcriptase for cDNA synthesis. Real-time polymerase chain reactions (PCRs) were then performed in a $7300 \mathrm{Re}-$ al-Time PCR System (Applied Biosystems, Foster City, CA, USA) using $3 \mathrm{~mL}$ of cDNA template, $1 \mathrm{nmol}$ of primers, and $12.5 \mathrm{~mL}$ of Power SYBR Green PCR Master Mix (Applied Biosystems) in a total reaction volume of $25 \mathrm{~mL}$. PCR was performed using the following primers for MUC4 (sense sequence, 5'-GACTTGGAGCTCTTTGAGAATGG-3'; anti-sense sequence, $5^{\prime}$-TGCAATGGCAGACCACAGTCC-3'; 138 bp) and GAPDH (glyceraldehyde3-phosphate dehydrogenase) (sense sequence, $5^{\prime}$-GCAAATTCCATGGCACCGT- $3^{\prime}$; anti-sense sequence, $5^{\prime}$-TCGCCCCACTTGATTTTG1G-3'; 106 bp). Amplification reactions were per-

Int Arch Allergy Immunol 2016;171:209-216 


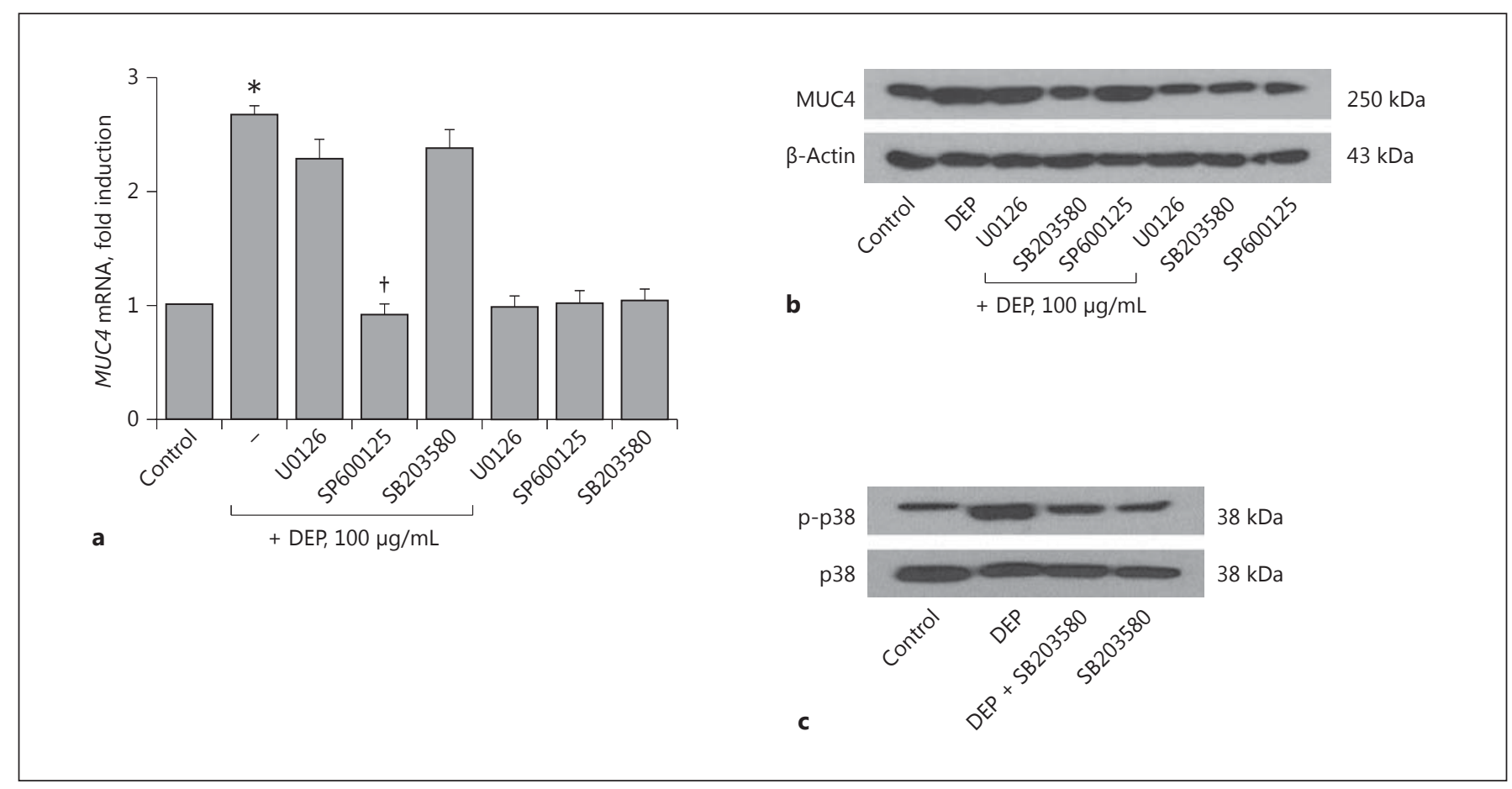

Fig. 3. Signaling molecules involved in DEP-induced MUC4 expression. NCI-H292 cells were pretreated with MAPK inhibitors (U0126, SB203580, and SP600125; $10 \mu \mathrm{M}$ each) and then treated with DEPs. Expression of MUC4 mRNA and protein was determined by RT-PCR (a) and Western blotting (b). Phosphorylation of p38 in DEP-treated NCI-H292 cells with or without SB203580 treatment was examined by Western blotting (c). Means \pm SEM of 3 independent experiments. ${ }^{*} p<0.05$ vs. control; ${ }^{\dagger} p<0.05$ vs. DEPs alone. U0126, ERK inhibitor; SB203580, p38 inhibitor; SP600125, JNK inhibitor. formed as follows: an initial denaturation step at $94^{\circ} \mathrm{C}$ for $10 \mathrm{~min}$, followed by 50 cycles at $95^{\circ} \mathrm{C}$ for $10 \mathrm{~s}, 58^{\circ} \mathrm{C}$ for $10 \mathrm{~s}$, and $72^{\circ} \mathrm{C}$ for $10 \mathrm{~s}$; a melting curve was generated. All reactions were performed in a $20-\mathrm{mL}$ volume. To confirm the amplification specificity, the PCR products obtained from each primer pair were subjected to melting curve analysis. Analysis of relative gene expression was performed by evaluating the quantitative RT-PCR data using the $2^{-\Delta \Delta C_{t}}$ method. The gene expression levels were normalized to that of GAPDH.

\section{Western Blot Analysis}

Cells $\left(6 \times 10^{5}\right.$ cells/60-mm dish) were lysed in PRO-PREPTM protein extraction solution (iNtRON Biotechnology, Seongnam, Korea). Lysates were separated by $10 \%$ SDS-PAGE and transferred onto polyvinyl difluoride membranes (Millipore Inc., Billerica, MA, USA). The membranes were blocked with $5 \%$ skim milk solution and incubated with the following antibodies: MUC4, p-p38, total-p38, p-CREB, total-CREB, and $\beta$-actin. The blots were visualized with HRP-conjugated secondary antibodies and an ECL system (Pierce, Rockford, IL, USA).

\section{Statistical Analysis}

Results were obtained from at least 3 independent experiments. The statistical significance of differences between the control and experimental data was analyzed with an unpaired $t$ test or 1-way analysis of variance followed by Tukey's test (GraphPad Prism, version 5; GraphPad Software, San Diego, CA, USA). Significance was established at the $95 \%$ confidence level. $p$ values less than 0.05 were accepted as statistically significant.

\section{Results}

DEPs Stimulate MUC4 Production in NCI-H292 Cells

We first examined the cytotoxic effect of DEPs on NCI-H292 cells using the MTT assay. DEPs did not show any cytotoxic effects after a 72-h exposure up to a concentration of $200 \mu \mathrm{g} / \mathrm{ml}$ (Fig. 1). We evaluated the ability of DEPs to stimulate MUC4 mRNA gene expression. Cells were treated with DEPs $(25,50$, and $100 \mu \mathrm{g} / \mathrm{ml})$, and the expression of MUC4 mRNA was determined by RTPCR after $12 \mathrm{~h}$. Treatment with DEPs significantly increased the expression of MUC4 mRNA in a dose-dependent manner (Fig. 2a). We determined whether DEPs could stimulate MUC4 protein expression in NCI-H292 cells by Western blotting. In a similar manner, cells were treated with DEPs for $72 \mathrm{~h}$. Treatment with DEPs increased the expression of MUC4 protein in NCI-H292 

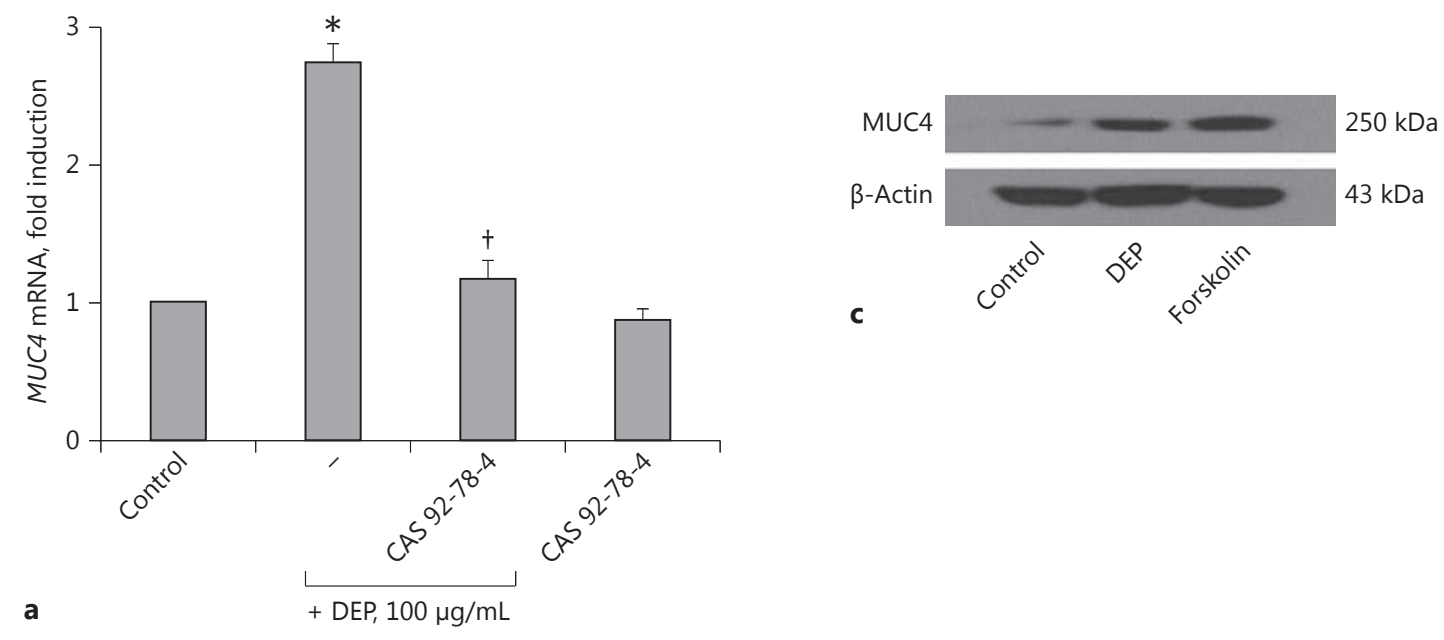

+ DEP, $100 \mu \mathrm{g} / \mathrm{mL}$
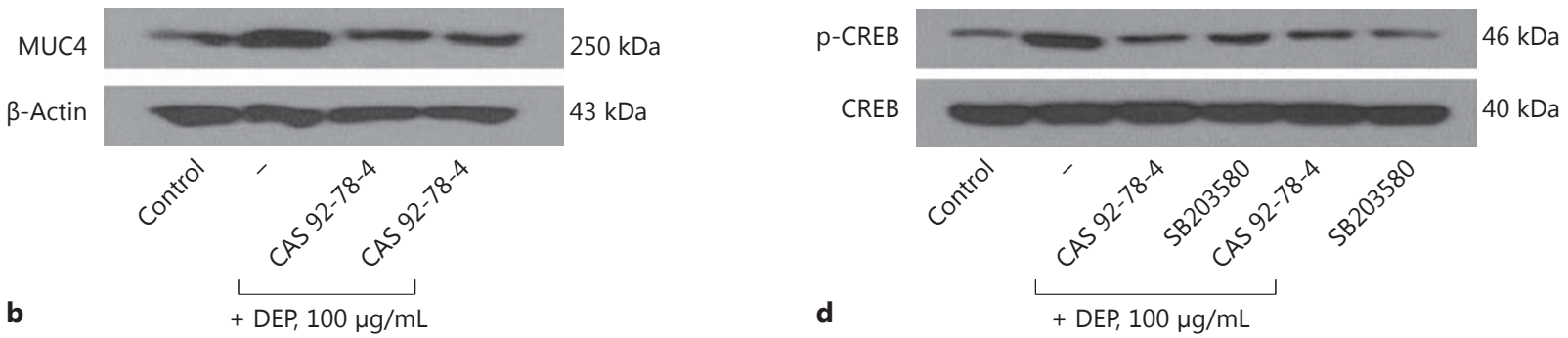

Fig. 4. CREB activation upon DEP-induced MUC4 expression in NCI-H292 cells. NCI-H292 cells were pretreated with CREB inhibitor (CAS 92-78-4; $100 \mu \mathrm{g} / \mathrm{mL}$ ) and then treated with DEPs. Expression of MUC4 mRNA and protein was determined by RTPCR (a) and Western blotting (b). NCI-H292 cells were pretreated with CREB activator (forskolin; $40 \mu \mathrm{M}$ ) and then treated with

DEPs. Expression of MUC4 protein was determined by Western blotting (c). Phosphorylation of CREB in NCI-H292 cells treated with DEP and with CAS 92-78-4 or SB203580 was examined by Western blotting (d). Means \pm SEM of 3 independent experiments. ${ }^{*} p<0.05$ vs. control; ${ }^{\dagger} p<0.05$ vs. DEPs only. SB203580, p38 inhibitor; CAS 92-78-4, CREB inhibitor.

cells (Fig. 2b). To confirm this finding, immunofluorescence staining of MUC4 protein was performed. Treatment with DEPs for $72 \mathrm{~h}$ was found to increase MUC4 protein levels (Fig. 2c).

\section{p38 Regulates the Production of MUC4 by DEPs in}

NCI-H292 Cells

To determine the effect of DEPs on intracellular signaling for MUC4 production in NCI-H292 cells, 3 MAPKs (p38, ERK 1/2, and JNK) were evaluated. NCIH292 cells were pretreated with MAPK inhibitors (ERK

inhibitor: U0126; p38 inhibitor: SB203580; and JNK inhibitor: SP600125) for $1 \mathrm{~h}$ and then treated with DEPs. After $12 \mathrm{~h}$ of treatment, the expression of MUC4 mRNA was significantly inhibited only by the p38 inhibitor (Fig. 3a). The protein level of MUC4 determined after $72 \mathrm{~h}$ was also decreased by the p 38 inhibitor (Fig. 3b). We examined the activation of $\mathrm{p} 38$ signaling protein by DEPs using Western blot analysis. Cells treated with DEPs for 15 min showed increased phosphorylation of p38 (Fig. 3c). 


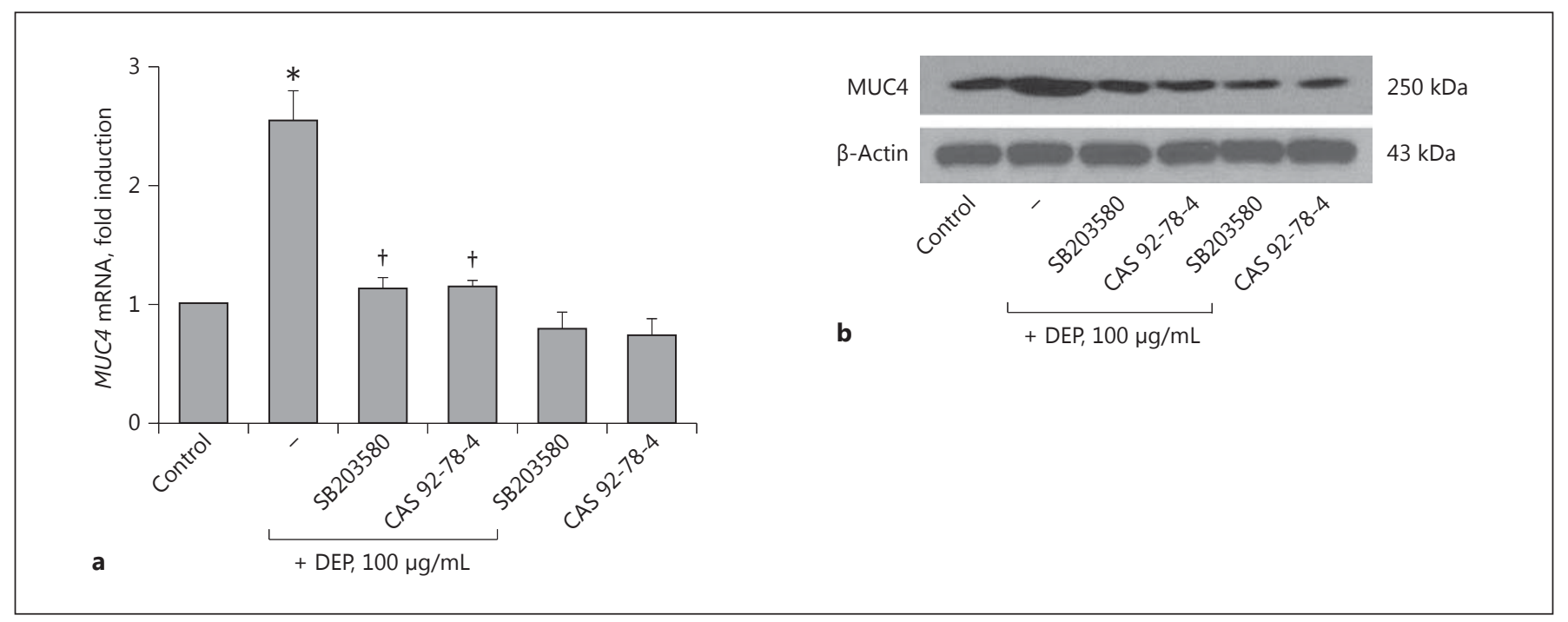

Fig. 5. Expression of MUC4 mRNA and protein in PNECs stimulated with DEPs. PNECs were pretreated with SB203580 $(10 \mu \mathrm{M})$ or CAS 92-78-4 $(100 \mu \mathrm{g} / \mathrm{mL})$ and then treated with DEPs. Expression of MUC4 mRNA and protein was determined by RT-PCR (a) and Western blotting (b). Means \pm SEM of 3 independent experiments. ${ }^{*} p<0.05$ vs. control. ${ }^{\dagger} p<0.05$ vs. DEPs alone. SB203580, p38 inhibitor; CAS 92-78-4, CREB inhibitor.

CREB Regulates the Production of MUC4 by DEPs in NCI-H292 Cells

To explore the role of the CREB signaling pathway in the expression of MUC4 in DEP-stimulated NCI$\mathrm{H} 292$ cells, cells were treated with DEPs with or without the CREB inhibitor (CAS 92-78-4). In NCI-H292 cells, MUC4 mRNA expression determined by RT-PCR was inhibited by the CREB inhibitor after $12 \mathrm{~h}$ of DEP treatment (Fig. 4a). Western blot analysis results after $72 \mathrm{~h}$ of DEP treatment mirrored the RT-PCR results (Fig. 4b). We also determined whether other activators of CREB such as forskolin can lead to MUC4 protein expression. In Western blot analysis, treatment of forskolin $(40 \mu \mathrm{M})$ for $72 \mathrm{~h}$ increased the expression of MUC4 protein (Fig. 4c). Using Western blotting, we confirmed that phosphorylation of CREB is inhibited not only by the CREB inhibitor but also by the p38 inhibitor (Fig. 4d). These results indicate that DEPs induced the expression of MUC4 via the p38/CREB pathway in NCI-H292 cells.

DEPs Induce MUC4 Expression in PNECs via the p38/ CREB Pathway

We evaluated whether DEPs could also stimulate MUC4 gene and protein expression in PNECs. PNECs were pretreated with the p38 inhibitor or the CREB inhibitor for $1 \mathrm{~h}$, and then stimulated with DEPs for $12 \mathrm{~h}$ (for RT-PCR) or $72 \mathrm{~h}$ (for Western blotting). Pretreatment with the p38 and CREB inhibitors prevented DEPinduced MUC4 mRNA and protein expression in PNECs (Fig. 5a, b). In general, experiments with PNECs produced results similar to those obtained with NCI-H292 cells.

\section{Discussion}

The present study showed that MUC4 mRNA and protein expression was significantly increased by DEPs in NCI-H292 cells and PNECs. DEPs stimulated the expression of MUC4 mRNA and protein in a dose-dependent manner in NCI-H292 cells. When DEP-stimulated NCIH292 cells were treated with specific inhibitors of p38, ERK, and JNK, only the p38 inhibitor reversed DEP-induced MUC4 production. The p38 inhibitor also inhibited DEP-induced MUC4 expression. DEPs increased p38 phosphorylation in NCI-H292 cells. A CREB inhibitor blocked the expression of MUC4 mRNA and protein in DEP-stimulated NCI-H292 cells as well as PNECs. CREB phosphorylation was inhibited not only by the CREB inhibitor, but also by the p38 inhibitor in both cells. Our results indicate that DEPs induce MUC4 mRNA and protein expression through the $\mathrm{p} 38 / \mathrm{CREB}$ pathway in NCI-H292 cells and PNECs. 
The underlying mechanisms by which DEPs exert their effects are not fully elucidated yet. The main concern related with DEPs is their composition. Although the composition of DEPs may vary widely depending on the engine type and composition of the fuel, DEPs mainly consist of solid carbonaceous materials, ash, and volatile organic and sulfur compounds [12]. The elemental carbon core has a large surface area, and hundreds of chemicals and transition metals are attached to it. Those attached to the elemental carbon core, especially transition metals, are supposed to participate in the generation of reactive oxygen species (ROS), which increase inflammation in the respiratory system [13]. Much concern related to the mechanisms by which DEPs exert their harmful effects involves ROS generation and oxidative stress in the exposed cells, and accumulating evidence supports the important role of oxidative stress in the harmful effects of DEPs. It is supposed that the induction of oxidative stress by DEPs leads to a series of reactions culminating in inflammation [14]. The size of DEPs is another point of concern. The size of spherical primary particles, which are the main component of typical DEPs, are about $15-40 \mathrm{~nm}$ in diameter, and the mean diameter of the agglomerated particles is in the range of 60-100 nm [15]. Thus, most DEPs can be classified as fine particles $\left(\mathrm{PM}_{2.5}\right)$ or ultrafine particles $\left(\mathrm{PM}_{0.1}\right)$. The ultrafine particles are small enough to have direct access to intracellular proteins, organelles, and DNA [16]. They are hypothesized to disrupt mitochondrial structure by directly lodging in intracellular organelles, subsequently causing their destruction [17].

Airway mucus hypersecretion is recognized as an important pathophysiological characteristic in many respiratory diseases, including allergic rhinitis, chronic rhinosinusitis, asthma, and chronic obstructive pulmonary disease. Several studies have shown the close relationship between DEPs and airway mucus hypersecretion. Both chronic and acute exposure to DEPs induces mucus hypersecretion. Repeated intratracheal instillation of DEPs in mice causes proliferation of goblet cells and increased mucus secretion [18]. In a study using murine allergen provocation models, delivery of DEPs induced an acute increase in mucus production [19]. Fine DEPs themselves are also related to mucin production. $\mathrm{PM}_{2.5}$ induced MUC5AC mRNA in mouse trachea after $48 \mathrm{~h}$ of exposure, and MUC5AC mRNA and protein in human bronchial epithelial cells after $24 \mathrm{~h}$ of exposure [20]. Increased expression of MUC5AC by DEPs was also shown in human middle ear epithelial cells [10]. In the present study, we showed that DEPs induce MUC4 mRNA and protein expression in NCI-H292 cells and PNECs.
It is known that MAPK pathways are triggered by exposure to DEPs in human respiratory epithelial cell lines. Hashimoto et al. [21] have revealed the role of p38 MAPK in DEP-induced IL-8 and RANTES production in human bronchial epithelial cells. MAPK pathways are also involved in DEP-induced release of GM-CSF [22]. Regarding the transcriptional factors involved, activation of MAPK by DEPs mainly leads to activation of NF- $\kappa$ B. In the present study, DEPs also exert their effects via p38 MAPK. However, exposure to DEPs was associated with CREB instead of NF- $\kappa$ B.

In the present study, DEPs induced MUC4 mRNA and protein expression via $\mathrm{p} 38$ and CREB pathways in NCIH292 cells and PNECs. To the best of our knowledge, this is the first study showing that DEPs induce the expression of transmembrane mucins in the respiratory epithelium. We assume that the mucus profile of respiratory epithelium upon DEP exposure could hamper the respiratory defense mechanism, subsequently causing several respiratory diseases related to mucus hypersecretion, and the results of the present study provide the basis for further investigation of the role of MUC4 in DEP-induced hypersecretion in airway epithelium.

\section{Acknowledgments}

This study was supported by a grant from the Korean Health Technology R\&D Project, Ministry of Health and Welfare, Republic of Korea (HI15C1512), and a Basic Science Research Program through the National Research Foundation of Korea (NRF) funded by the Ministry of Science, ICT, and Future Planning (NRF2015R1C1A1A02037312).

\section{Disclosure Statement}

The authors have no conflict of interest.

References

Int Arch Allergy Immunol 2016;171:209-216

1 Rogers DF: Physiology of airway mucus secretion and pathophysiology of hypersecretion. Respir Care 2007;52:1134-1146; discussion 1146-1139.

2 Fahy JV, Dickey BF: Airway mucus function and dysfunction. N Engl J Med 2010;363: 2233-2247.

3 Kim KC: Role of epithelial mucins during airway infection. Pulm Pharmacol Ther 2012;25: 415-419.

4 Chaturvedi P, Singh AP, Batra SK: Structure, evolution, and biology of the MUC4 mucin. FASEB J 2008;22:966-981. 
5 Widory D, Roy S, Moullec YL, Goupil G, Cocherie A, Guerrot C: The origin of atmospheric particles in Paris: a view through carbon and lead isotopes. Atmos Environ 2004;38: 953-961.

6 Ristovski ZD, Miljevic B, Surawski NC, Morawska L, Fong KM, Goh F, Yang IA: Respiratory health effects of diesel particulate matter. Respirology 2012;17:201-212.

7 Gamble J, Jones W, Minshall S: Epidemiological-environmental study of diesel bus garage workers: chronic effects of diesel exhaust on the respiratory system. Environ Res 1987;44: 6-17.

8 McCreanor J, Cullinan P, Nieuwenhuijsen MJ, Stewart-Evans J, Malliarou E, Jarup L, Harrington R, Svartengren M, Han IK, Ohman-Strickland P, Chung KF, Zhang J: Respiratory effects of exposure to diesel traffic in persons with asthma. N Engl J Med 2007;357: 2348-2358.

9 Riedl M, Diaz-Sanchez D: Biology of diesel exhaust effects on respiratory function. J Allergy Clin Immunol 2005;115:221-228; quiz 229.

10 Song JJ, Lee JD, Lee BD, Chae SW, Park MK: Effect of diesel exhaust particles on human middle ear epithelial cells. Int J Pediatr Otorhinolaryngol 2012;76:334-338.
11 Gluck U, Schutz R, Gebbers JO: Cytopathology of the nasal mucosa in chronic exposure to diesel engine emission: a five-year survey of Swiss customs officers. Environ Health Perspect 2003;111:925-929.

12 Kittleson DB: Engines and nanoparticles: a review. J Aerosol Sci 1998;29:575-588.

13 Lim J, Lim C, Yu LE: Composition and size distribution of metals in diesel exhaust particulates. J Environ Monit 2009;11:16141621.

14 Ghio AJ, Smith CB, Madden MC: Diesel exhaust particles and airway inflammation. Curr Opin Pulm Med 2012;18:144-150.

15 Burtscher H: Physical characterization of particulate emissions from diesel engines: a review. J Aerosol Sci 2005;36:896-932.

16 Geiser M, Rothen-Rutishauser B, Kapp N, Schurch S, Kreyling W, Schulz H, Semmler M, Im Hof V, Heyder J, Gehr P: Ultrafine particles cross cellular membranes by nonphagocytic mechanisms in lungs and in cultured cells. Environ Health Perspect 2005;113: 1555-1560.

17 Li N, Sioutas C, Cho A, Schmitz D, Misra C, Sempf J, Wang M, Oberley T, Froines J, Nel A: Ultrafine particulate pollutants induce oxidative stress and mitochondrial damage. Environ Health Perspect 2003;111:455-460.
18 Sagai M, Furuyama A, Ichinose T: Biological effects of diesel exhaust particles (DEP). III. Pathogenesis of asthma like symptoms in mice. Free Radic Biol Med 1996;21:199-209.

19 Hao M, Comier S, Wang M, Lee JJ, Nel A: Diesel exhaust particles exert acute effects on airway inflammation and function in murine allergen provocation models. J Allergy Clin Immunol 2003;112:905-914.

20 Val S, Belade E, George I, Boczkowski J, Baeza-Squiban A: Fine PM induce airway MUC5AC expression through the autocrine effect of amphiregulin. Arch Toxicol 2012;86: 1851-1859.

21 Hashimoto S, Gon Y, Takeshita I, Matsumoto K, Jibiki I, Takizawa H, Kudoh S, Horie T: Diesel exhaust particles activate p38 MAP kinase to produce interleukin 8 and RANTES by human bronchial epithelial cells and $\mathrm{N}$ acetylcysteine attenuates p38 MAP kinase activation. Am J Respir Crit Care Med 2000; 161:280-285.

22 Bonvallot V, Baeza-Squiban A, Boland S, Marano F: Activation of transcription factors by diesel exhaust particles in human bronchial epithelial cells in vitro. Inhal Toxicol 2000; 12(suppl 3):359-364 